\title{
Substitution and price elasticity estimates using inter-country pooled data in a translog cost model
}

\author{
Joyashree Roy \\ Department of Economics and coordinator global Change Programme
}

\author{
Alan H. Sanstad, Jayant A. Sathaye \\ Energy Analysis-LBNL
}

Raman Khaddaria

Global Change Programme

\begin{abstract}
Pooled data across several developing countries and the U. S. were used to estimate long-run substitution and price elasticities in a translog framework for the paper, iron and steel, and aggregate manufacturing industries. While the quality of the estimates varies across the several industry-specific models, the results suggest higher values for these elasticities than appear commonly used in integrated assessment models. Estimates of own-price elasticities of energy range from -0.80 to -1.76 and are comparable to estimates from previous econometric studies in the context of developed countries $(-0.77$ to -0.87$)$. Substitution elasticities show wider variation across countries and industries. For energy and capital they range from -1.96 to 9.80 , for labor and energy from 2.61 to 7.11 , and for energy and material from -0.26 to 2.07.
\end{abstract}

Keywords: Integrated Assessment Model; Translog; Fuel and input; Elasticity; Industry; India; Brazil; South Korea; US 


\section{Background}

Integrated assessment (IA) modeling has become increasingly focused upon understanding the regional impacts of both climate change and greenhouse gas mitigation policies. Analyzing such impacts requires the maximum possible use of country or region-specific economic information, including model parameters. Among the most important parameters in this context are those governing inter-input and inter-fuel substitution possibilities and technological change. This paper presents country-specific and inter-country estimates of substitution elasticities obtained from a pooled sample. We apply a framework (Christensen et al., 1971, Jorgenson and Fraumeni, 1981 and Jorgenson et al., 1987) used by several researchers in the mid-1970s and early-1980s for estimating long-run elasticities using international or intra-country regional data pooled over a time period (Griffin and Gregory, 1976, Pindyck, 1979 and Fuss, 1977). Such pooling increases both the range and the number of sources of variation in the data, in both input and output prices. The time series component reflects dynamic adjustments due to changing relative prices, technical progress, and external shocks, while the cross country component reflects both structural differences and the natural range of price variation among regions (Griffin and Gregory, 1976). Particularly on the input side, pooling captures wide inter-country variation due to national labor rules, tariffs, fiscal policies, subsidies, and foreign trade policies.

The added variation gained through pooling is particularly useful in applying the translog functional form, as we do in the work reported here. As is well-known, the regularity properties of a given translog model (non-negativity, monotonicity, and concavity) can fail outside the sample used for estimation (Ryan and Wales, 2000 and Perroni and Rutherford, 1998). This problem can be particularly severe using single-country data (Roy, 1992, Roy, 1995 and Roy et

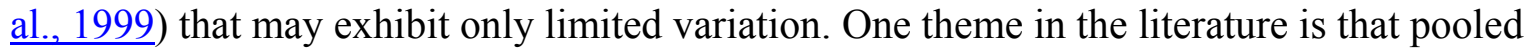
samples can provide robustness, partially offsetting this problem.

\section{Comparison with past studies}

Inter-country studies by Pindyck (1979), Griffin and Gregory (1976) focused on developed countries only. (See Table 1). Fuss used (1977) interregional data for Canada. The present study uses data for South Korea, Brazil, India (Schumacher et al., 2000) and the United States. While these earlier studies treated only aggregate manufacturing, the analysis presented in this paper encompasses several energy-intensive industries as well as aggregate manufacturing. 
Table 1. Cross country studies

\begin{tabular}{|l|l|l|l|l|}
\hline Author/s & Category & Countries & Inputs & Years \\
\hline $\begin{array}{l}\text { Griffin and } \\
\text { Gregory }\end{array}$ & Five Year interval/manufacturing & $\begin{array}{l}\text { 9-developed } \\
\text { countries }\end{array}$ & K,L, E & $\begin{array}{l}1955,1960, \\
1965,1969\end{array}$ \\
\hline Pindyck & Annual/manufacturing & $\begin{array}{l}\text { 10 Developed } \\
\text { countries }\end{array}$ & $\begin{array}{l}\text { K,L,E Fuels: } \\
\text { C,O,e,NG }\end{array}$ & $1963-73$ \\
\hline Roy et al. & $\begin{array}{l}\text { Annual/3 developing countries and US for paper, } \\
\text { 3-developing countries for aggregate } \\
\text { manufacturing and 2-developing countries for iron } \\
\text { and steel }\end{array}$ & $\begin{array}{l}\text { 3 developing } \\
\text { countries and } \\
\text { US }\end{array}$ & K, L, E, M & $1980-1993$ \\
\hline
\end{tabular}

Note: $\mathrm{K}=$ capital, $\mathrm{L}=$ labor, $\mathrm{E}=$ energy, $\mathrm{C}=$ coal, $\mathrm{O}=$ oil, $\mathrm{e}=$ electricity, $\mathrm{NG}=$ natural gas, $\mathrm{M}=$ materials.

\section{Theoretical framework and econometric approach}

In contrast to the inter-country work cited above, we include a materials input explicitly. For each modeled industry, we assume the existence of a twice-differentiable production function transforming capital, labor, energy and materials (K, L, E, M) into gross output. We further assume constant-returns-to-scale and homotheticity. The generic function can be written as

$$
Q=f\left(X_{k}, X_{l}, X_{e}, X_{m}, t\right)
$$

where $Q$ is the sectoral output, and $X_{k}, X_{l}, X_{e}$ and $X_{m}$ are the sectoral inputs of capital, labor, energy and materials, respectively. The maintained assumptions imply the existence of a dual unit cost function giving output price as a function of input prices:

$$
c=g\left(P_{k} P_{l}, P_{e}, P_{m}, t\right) \text {. }
$$

Moreover, expenditure shares for each of the inputs can be expressed in terms of derivatives of the cost function

$$
M_{i}=\frac{\partial \operatorname{Ing}}{\partial \ln P_{i}}=\frac{p_{i} X_{i}}{\sum p_{i} X_{i}} \quad i=k, k_{2}, m
$$

We adopt a translog functional form, so the dual unit cost function or output price can be written as

$$
\ln c^{s}=\ln a_{0}^{s}+\sum_{i} a_{i}^{s} \ln p_{i}^{s}+a_{i}^{s} t+\frac{1}{2} \sum_{i} \sum_{j} b_{i j}^{s} \ln p_{i}^{s} \ln p_{i}^{s}+\sum_{i} b_{i}^{s} \ln p_{i}^{s} t+\frac{1}{2} b_{i t}^{s} t^{2}
$$

for $i, j=K, L, E, M$ and $\mathrm{s}=$ sectors (three energy-intensive industrial sectors, aggregate

manufacturing). 
Linear homogeneity of the price function follows from the parametric restrictions:

$$
\begin{gathered}
\sum_{i} a_{i}^{s}=1, \\
\sum_{i} b_{i j}^{s}=\sum_{i} b_{i j}^{s}=0, i \neq j \\
\sum_{i} b_{i t}^{s}=0
\end{gathered}
$$

Symmetry of share elasticities imply the further restriction:

$$
b_{i v}^{s}=b_{s}^{f}, \quad l \neq j
$$

Value or cost shares of capital, labor, energy and materials are derivatives of the cost function as shown in Eq. (3):

$$
M_{i}^{s}=\alpha_{i}^{s}+\sum_{j} b_{i j}^{\varepsilon} \ln p_{j}^{\mathrm{s}}+b_{i k}^{\mathrm{e}} \epsilon_{r} \quad \forall i
$$

For single-country and/or industry estimations, the common approach is to add an error term to Eq. (7) and estimate a model consisting of three of the four share equations along with the cost function. (One share equation is dropped to avoid singularity.) However, directly applying the model defined by (three of) the cost shares in Eq. (7) together with the cost function to pooled (inter-country) data would entail the implausible assumption that all the cross sectional units (i.e., the individual countries) are represented by the same production function. To overcome this problem we assume that each cross sectional unit has a different efficiency level. In estimating the model with varying efficiencies a choice must be made as to whether the first order coefficients (the ones with a single subscript) and/or second order coefficients (two subscripts) in the country-specific share equations should be allowed to vary. Allowing both sets of parameters to vary would mean that the time series and cross sectional data is not pooled, rather a separate model for each state (time series) or each year (cross section) is estimated. This would require more data points than are available and would result in short-run elasticities. If we allow the second order terms to vary only, we are left with very few degrees of freedom as well. We, therefore, allow the first order coefficients to vary across countries. This can be introduced by inclusion of separate intercept terms for the cross sectional units (Binswanger, 1978, Pindyck, $\underline{1979}$, Fuss, 1977 and Roy et al., 2001), which implies, for our models, the inclusion of country dummies in the share equations.

Including these dummies and adding an error term the share equations defined through Eq. (7) become:

$$
M_{i}^{s}=\alpha_{i}^{s}+\sum_{j} E_{i j}^{s} \ln p_{j}^{s}+b_{i i}^{s} t+\sum_{\xi} \delta_{i k}^{s} \mathrm{dum}_{r}+t_{i, r}^{s} \quad \forall i
$$

with

$\delta_{i r}$

share specific country dummies

dum $_{r}$ 
1 for countries other than India

0 for India

$i$

capital, labor, energy and material

Estimation with intercept dummies is equivalent to estimating the covariance model of the implicit error terms in the equations, where error terms are composed of a regional component and a total component (Fuss, 1977, Pindyck, 1979 and Greene, 1997). We drop one of the share equations to avoid singularity, and add the cost function to the system. We ignore autocorrelation but take account of correlation of error terms among equations, and thus use Iterative Zellnerefficient estimation.

From the parameter estimates of the above model we can derive Allen Elasticities of Substitution $\left(\mathrm{AES}, \sigma_{i j}\right)$ and price elasticities $\left(E_{i j}\right)$ :

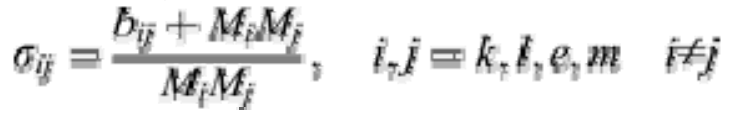

$$
\begin{aligned}
& \sigma_{\ddot{u}}=\frac{b_{i}+M_{i}^{2}-M_{i}}{M f_{i}^{2}}, \quad l, j=k, l, e, m \quad l=l \\
& E_{i j}=M_{j} \sigma_{i j}
\end{aligned}
$$

The parameters $a_{i}$ can be interpreted as average value shares of capital, labor, energy and materials inputs for the corresponding sector, and $a_{t}$ as the average of the negative of rates of (sectoral) technological change or "pure" productivity improvement. $b_{i t}$ has a two-fold interpretation. It represents the change in share of the $i$ th input over time when relative factor prices are held constant that is, it is the impact of technology trends on input shares, or "factor price bias". Under the assumptions of the model, it displays also the impact on the trend in total factor productivity with changing input prices. $b_{t t}$ can be interpreted as constant rates of change or acceleration of the negative of the rates of technical change. If the estimated value is positive, the rate of technical change is decreasing. And if negative, the rate is increasing.

\section{Data}

Data for India, South Korea, and Brazil were obtained from various government sources (Bank of Korea 1 (various years), Bank of Korea 2 (various years), Fundacao Instituto Brasileiro de Geografia e Estatistica (IBGE 1) (various years), Fundacao Instituto Brasileiro de Geografia e Estatistica (IBGE 2) (various years), Government of India 1 (various years) and Government of India 2 (various years)). (Details on the construction of the data sets used in the estimations involving these countries are available from the first author.) Data for the U. S. were obtained from the website of Prof. Dale Jorgenson at Harvard University.. Our conversions are based upon purchasing power parity (ppp). We use ppp values for producing the pooled data set. We accept that converting country data to common currencies usually US dollars at existing exchange rates is misleading because exchange rates do not necessarily reflect the purchasing power of currencies. ppp values are the geometric mean (usually the unweighted) of price ratios of items; give the number of units of a country's currency that have the same purchasing power for the category as a US dollar (Kravis et al., 1978). 
Because the industry definitions in the data do not correspond exactly across countries, we pooled the data in three different combinations to reflect the sources of the data: a) the paper industry for Indian, South Korea, Brazil, and the U.S., b) aggregate manufacturing for India, South Korea, and Brazil, c) iron and steel for India and South Korea. Table 2 shows the range of variation in the data corresponding to these combinations, and indicates the increased variation gained by pooling.

Table 2. Range of variation in price indices over the period 1980-1993

\begin{tabular}{|c|c|c|c|c|c|}
\hline Aggregate manufacturing & Capital & Labor & Energy & Material & Output \\
\hline \multicolumn{6}{|l|}{ Brazil } \\
\hline Min & 119.3 & 58.4 & 120.7 & 61.5 & 61.5 \\
\hline Max & $3.79 \mathrm{E}+11$ & $2.79 \mathrm{E}+11$ & $2.96 \mathrm{E}+11$ & $9.7 \mathrm{E}+10$ & $1.81 \mathrm{E}+11$ \\
\hline \multicolumn{6}{|l|}{ India } \\
\hline Min & 130.2 & 42.3 & 34.3 & 41.9 & 41.9 \\
\hline Max & 339.9714 & 177.8918 & 108.5983 & 95.86177 & 107.4518 \\
\hline \multicolumn{6}{|l|}{ Korea } \\
\hline Min & 93.4 & 64.6 & 245.6 & 59.1 & 61.5 \\
\hline Max & 135.8545 & 374.655 & 280.3387 & 78.96907 & 85.04934 \\
\hline \multicolumn{6}{|l|}{ Pooled data set } \\
\hline Min & 93.4 & 42.3 & 34.3 & 41.9 & 41.9 \\
\hline Max & $3.79 \mathrm{E}+11$ & $2.79 \mathrm{E}+11$ & $2.96 \mathrm{E}+11$ & $9.7 \mathrm{E}+10$ & $1.81 \mathrm{E}+11$ \\
\hline \multicolumn{6}{|l|}{ Iron and steel } \\
\hline \multicolumn{6}{|l|}{ India } \\
\hline Min & 130.2 & 42.3 & 34.3 & 41.9 & 41.9 \\
\hline Max & 340 & 171.2 & 108.6 & 98.4 & 129 \\
\hline \multicolumn{6}{|l|}{ Korea } \\
\hline Min & 93.4 & 64.6 & 245.6 & 59.1 & 61.5 \\
\hline Max & 135.9 & 366.2 & 359.3 & 78.9 & 85.4 \\
\hline \multicolumn{6}{|l|}{ Pooled data set } \\
\hline Min & 93.4 & 42.3 & 34.3 & 41.9 & 41.9 \\
\hline Max & 340 & 366.2 & 359.3 & 98.4 & 129 \\
\hline \multicolumn{6}{|l|}{ Paper } \\
\hline \multicolumn{6}{|l|}{ Brazil } \\
\hline Min & 119.3 & 58.4 & 120.7 & 61.5 & 61.5 \\
\hline Max & $3.79 \mathrm{E}+11$ & $2.98 \mathrm{E}+11$ & $2.96 \mathrm{E}+11$ & $9.7 \mathrm{E}+10$ & $1.73 \mathrm{E}+11$ \\
\hline \multicolumn{6}{|l|}{ India } \\
\hline Min & 130.2 & 42.3 & 34.3 & 41.9 & 41.9 \\
\hline Max & 339.9714 & 159.0001 & 108.5983 & 41.9 & 148.0097 \\
\hline \multicolumn{6}{|l|}{ Korea } \\
\hline Min & 93.4 & 64.6 & 245.6 & 59.1 & 61.5 \\
\hline Max & 135.8545 & 347.603 & 359.2902 & 78.96907 & 86.50785 \\
\hline \multicolumn{6}{|l|}{ US } \\
\hline Min & 100 & 100 & 100 & 100 & 99.7 \\
\hline
\end{tabular}




\begin{tabular}{|l|l|l|l|l|l|}
\hline Aggregate manufacturing & Capital & Labor & Energy & Material & Output \\
\hline Max & 169.8387 & 167.8689 & 127.7001 & 145.6241 & 141.0984 \\
\hline Pooled & & & & & \\
\hline Min & 93.4 & 42.3 & 34.3 & 41.9 & 61.5 \\
\hline Max & $3.79 \mathrm{E}+11$ & $2.98 \mathrm{E}+11$ & $2.96 \mathrm{E}+11$ & $9.7 \mathrm{E}+10$ & $1.73 \mathrm{E}+11$ \\
\hline
\end{tabular}

\section{Results}

The results of the regressions are given in Table 3, corresponding to the three different "pools." Local concavity - i.e., concavity at each observation in the sample(s) - was found (by direct calculation) to be satisfied for each set of estimations. Regarding significance of the individual parameter estimates at the 10\% level: Among the first-order parameters, five out of six are significant for each of the three regressions. Among the second-order parameters, all fifteen are significant for aggregate manufacturing, while ten of fifteen are significant for paper and three of fifteen for iron and steel. Among the dummy variables, thirteen of fifteen for paper, nine of ten for aggregate manufacturing, and one of five for iron and steel, are significant.

Table 3. Parameter estimates

\begin{tabular}{|c|c|c|c|c|c|c|}
\hline \multirow[t]{2}{*}{ Parameter } & \multicolumn{2}{|l|}{ Paper } & \multicolumn{2}{|c|}{ Aggregate manufacturing } & \multicolumn{2}{|l|}{ Iron and steel } \\
\hline & Estimate & $t$ & Estimate & $t$ & Estimate & $t$ \\
\hline$a_{0}$ & -0.453 & -11.744 & -0.392 & -9.388 & -0.274 & -2.875 \\
\hline$a_{k}$ & 0.511 & 14.454 & 0.309 & 14.887 & 0.444 & 2.931 \\
\hline$a_{l}$ & 0.036 & 4.023 & 0.027 & 3.748 & 0.075 & 5.531 \\
\hline$a_{e}$ & 0.084 & 8.980 & 0.013 & 1.908 & 0.077 & 1.485 \\
\hline$a_{m}$ & 0.368 & 12.316 & 0.652 & 34.310 & 0.404 & 2.765 \\
\hline$a_{t}$ & -0.008 & -1.024 & -0.004 & -0.459 & -0.011 & -2.014 \\
\hline$b_{k k}$ & -0.115 & -3.413 & -0.066 & -3.567 & -0.107 & -0.857 \\
\hline$b_{k l}$ & 0.054 & 6.688 & 0.065 & 11.822 & 0.002 & 0.156 \\
\hline$b_{k e}$ & 0.026 & 3.023 & 0.044 & 7.660 & 0.023 & 0.577 \\
\hline$b_{k m}$ & 0.034 & 1.212 & -0.043 & -2.690 & 0.082 & 0.693 \\
\hline$b_{k t}$ & 0.006 & 4.264 & 0.002 & 2.070 & 0.011 & 7.157 \\
\hline$b_{l l}$ & -0.010 & -3.215 & -0.008 & -2.569 & 0.002 & 1.099 \\
\hline$b_{l e}$ & -0.012 & -3.956 & -0.008 & -4.216 & -0.001 & -0.331 \\
\hline$b_{l m}$ & -0.033 & -4.679 & -0.050 & -10.235 & -0.003 & -0.272 \\
\hline$b_{l t}$ & -0.004 & -8.761 & -0.006 & -12.229 & -0.004 & -21.605 \\
\hline$b_{e e}$ & 0.008 & 0.751 & 0.003 & 0.555 & -0.058 & -1.503 \\
\hline$b_{e t}$ & -0.001 & -2.643 & -0.002 & -5.074 & -0.004 & -2.880 \\
\hline$b_{m m}$ & 0.021 & 0.730 & 0.133 & 7.529 & -0.115 & -0.887 \\
\hline$b_{e m}$ & -0.022 & -2.186 & -0.039 & -6.529 & 0.036 & 0.658 \\
\hline$b_{m t}$ & -0.001 & -0.864 & 0.005 & 4.373 & -0.003 & -1.345 \\
\hline$b_{t t}$ & 0.001 & 1.443 & 0.002 & 2.304 & 0.001 & 1.242 \\
\hline$\delta_{k 1}$ & -0.383 & -18.899 & -0.261 & -23.985 & -0.180 & -1.503 \\
\hline$\delta_{k 2}$ & -0.390 & -11.256 & -0.199 & -9.542 & & \\
\hline$\delta_{k 3}$ & -0.426 & -12.769 & & & & \\
\hline
\end{tabular}




\begin{tabular}{|c|c|c|c|c|c|c|}
\hline \multirow[t]{2}{*}{ Parameter } & \multicolumn{2}{|l|}{ Paper } & \multicolumn{2}{|c|}{ Aggregate manufacturing } & \multicolumn{2}{|l|}{ Iron and steel } \\
\hline & Estimate & $t$ & Estimate & $t$ & Estimate & $t$ \\
\hline$\delta_{l 1}$ & 0.040 & 6.190 & 0.047 & 10.323 & -0.009 & -0.755 \\
\hline$\delta_{l 2}$ & 0.058 & 5.855 & 0.078 & 10.860 & & \\
\hline$\delta_{l 3}$ & 0.233 & 27.838 & & & & \\
\hline$\delta_{e 1}$ & 0.000 & 0.039 & 0.015 & 2.269 & 0.101 & 1.688 \\
\hline$\delta_{e 2}$ & -0.032 & -1.605 & 0.014 & 1.184 & & \\
\hline$\delta_{e 3}$ & -0.027 & -2.903 & & & & \\
\hline$\delta_{m 1}$ & 0.342 & 16.532 & 0.198 & 16.580 & 0.089 & 0.786 \\
\hline$\delta_{m 2}$ & 0.364 & 11.965 & 0.107 & 5.805 & & \\
\hline$\delta_{m 3}$ & 0.220 & 7.576 & & & & \\
\hline$\delta_{\mathrm{TC} 1}$ & 0.127 & 5.019 & 0.293 & 10.256 & 0.100 & 1.386 \\
\hline$\delta_{\mathrm{TC} 2}$ & 0.149 & 4.229 & 0.228 & 6.952 & & \\
\hline$\delta_{\mathrm{TC} 3}$ & 0.366 & 11.702 & & & & \\
\hline
\end{tabular}

Note: With four countries, three dummies are included: $1=$ Brazil, 2. $=$ Korea, $3=$ US. India is the reference country.

For paper and aggregate manufacturing, inclusion of country intercepts to account for efficiency differences among the countries is supported by the significance in most instances of the country dummies. This implies that the panel data estimation with dummies accounts for efficiency and structural differences reflected through differences in input shares. They are consistent with the variations in actual shares, as shown in Table 4. India in general has a very high share for capital in total cost compared to all the countries. While labor cost is relatively much higher for the US industries, the energy cost shares are very close to one another across countries.

Table 4. Cross country variation in average (over the study period) cost shares

\begin{tabular}{|c|c|c|c|c|}
\hline & Capital & Labor & Energy & Material \\
\hline \multicolumn{5}{|c|}{ Aggregate manufacturing } \\
\hline Brazil & 8 & 9 & 6 & 76 \\
\hline India & 27 & 6 & 5 & 63 \\
\hline Korea & 20 & 8 & 3 & 69 \\
\hline Pooled & 18 & 8 & 5 & 69 \\
\hline \multicolumn{5}{|c|}{ Iron and steel } \\
\hline India & 40 & 5 & 7 & 48 \\
\hline Korea & 33 & 4 & 7 & 56 \\
\hline Pooled & 36 & 4 & 7 & 52 \\
\hline \multicolumn{5}{|l|}{ Paper } \\
\hline Brazil & 12 & 9 & 10 & 69 \\
\hline India & 44 & 6 & 10 & 40 \\
\hline Korea & 19 & 7 & 6 & 69 \\
\hline US & 12 & 25 & 5 & 58 \\
\hline Pooled & 22 & 12 & 8 & 59 \\
\hline
\end{tabular}


Allen and price elasticities are given in Table 5, Table 6, Table 7, Table 8, Table 9 and Table 10. Own-price elasticities show the correct sign. Own-price elasticities for capital are all greater than one or close to one (in absolute value). For paper and aggregate manufacturing, own elasticities are generally higher for capital and labor followed by energy and materials. This inelastic demand for material and energy relative to capital and labor shows the relative vulnerability of the sectors to energy and materials price fluctuations. The country-wise differences get reflected appropriately in their elasticity estimates as well. As expected they vary with their cost shares. Since in deriving the country-specific values we assume second order terms to remain unchanged and only change is in first order parameter, the changes arise due to variation in cost shares. One observation is that those with higher cost share for an input show lower elasticity compared to the countries where relative cost share is higher. e.g. capital cost share is higher in India (Table 4) compared to all other countries and we observe lower own-price elasticity for capital in India compared to other inputs.

Table 5. Allen elasticities, paper

\begin{tabular}{|c|c|c|c|c|c|c|c|c|c|c|}
\hline & Country pooled & $t$ & Korea & $t$ & India & $t$ & Brazil & $t$ & US & $t$ \\
\hline KK & -6.04 & -8.47 & -7.49 & -7.98 & -1.84 & -10.76 & -15.66 & -6.52 & -15.98 & 2.47 \\
\hline KL & 3.15 & 9.80 & 5.28 & 8.25 & 2.96 & 10.10 & 6.16 & 7.98 & 2.87 & 0.28 \\
\hline $\mathrm{KE}$ & 2.55 & 4.98 & 3.36 & 4.30 & 1.60 & 8.10 & 3.16 & 4.42 & 5.27 & 1.41 \\
\hline KM & 1.27 & 1.64 & 1.26 & 1.43 & 1.20 & 1.33 & 1.42 & 2.83 & 1.50 & 1.16 \\
\hline LL & -8.31 & -36.70 & -16.10 & -23.57 & -17.51 & -22.29 & -11.48 & -29.59 & -3.18 & 0.05 \\
\hline LE & -0.27 & -0.85 & -1.94 & -2.61 & -0.86 & -1.83 & -0.27 & -0.84 & 0.11 & 0.22 \\
\hline LM & 0.52 & 5.08 & 0.28 & 1.86 & -0.33 & -1.16 & 0.47 & 4.07 & 0.77 & 0.05 \\
\hline $\mathrm{EE}$ & -10.55 & -6.10 & -13.80 & -4.50 & -8.29 & -7.76 & -8.03 & -8.00 & -15.22 & 3.82 \\
\hline EM & 0.51 & 2.28 & 0.44 & 1.72 & 0.43 & 1.63 & 0.68 & 4.70 & 0.26 & 0.34 \\
\hline MM & -0.64 & -7.67 & -0.41 & -6.75 & -1.39 & -7.56 & -0.40 & -6.68 & -0.66 & 0.09 \\
\hline
\end{tabular}

Table 6. Price elasticities, paper

\begin{tabular}{|c|c|c|c|c|c|c|c|c|c|c|}
\hline & Country Pooled & $t$ & Korea & $t$ & Brazil & $t$ & India & $t$ & US & $t$ \\
\hline KK & -1.31 & -8.47 & -1.42 & -7.98 & -1.85 & -6.52 & -0.82 & -10.76 & -1.87 & -6.48 \\
\hline KL & 0.37 & 9.80 & 0.35 & 8.25 & 0.55 & 7.98 & 0.19 & 10.10 & 0.71 & 10.26 \\
\hline $\mathrm{KE}$ & 0.20 & 4.98 & 0.20 & 4.30 & 0.32 & 4.42 & 0.16 & 8.10 & 0.28 & 3.73 \\
\hline KM & 0.75 & 5.73 & 0.87 & 5.80 & 0.98 & 4.10 & 0.47 & 7.41 & 0.88 & 3.62 \\
\hline LK & 0.68 & 9.80 & 1.00 & 8.25 & 0.73 & 7.98 & 1.31 & 10.10 & 0.34 & 10.26 \\
\hline LL & -0.97 & -36.70 & -1.08 & -23.57 & -1.02 & -29.59 & -1.10 & -22.29 & -0.79 & -63.98 \\
\hline LE & -0.02 & -0.85 & -0.11 & -2.61 & -0.03 & -0.84 & -0.09 & -1.83 & 0.01 & 0.51 \\
\hline LM & 0.31 & 5.08 & 0.20 & 1.86 & 0.32 & 4.07 & -0.13 & -1.16 & 0.45 & 15.92 \\
\hline EK & 0.55 & 4.98 & 0.64 & 4.30 & 0.37 & 4.42 & 0.71 & 8.10 & 0.62 & 3.73 \\
\hline EL & -0.03 & -0.85 & -0.13 & -2.61 & -0.02 & -0.84 & -0.05 & -1.83 & 0.03 & 0.51 \\
\hline $\mathrm{EE}$ & -0.82 & -6.10 & -0.81 & -4.50 & -0.82 & -8.00 & -0.82 & -7.76 & -0.80 & -3.99 \\
\hline EM & 0.30 & 2.28 & 0.30 & 1.72 & 0.47 & 4.70 & 0.17 & 1.63 & 0.15 & 0.79 \\
\hline MK & 0.28 & 5.73 & 0.24 & 5.80 & 0.17 & 4.10 & 0.53 & 7.41 & 0.18 & 3.62 \\
\hline ML & 0.06 & 5.08 & 0.02 & 1.86 & 0.04 & 4.07 & -0.02 & -1.16 & 0.19 & 15.92 \\
\hline ME & 0.04 & 2.28 & 0.03 & 1.72 & 0.07 & 4.70 & 0.04 & 1.63 & 0.01 & 0.79 \\
\hline MM & -0.38 & -7.67 & -0.28 & -6.75 & -0.28 & -6.68 & -0.55 & -7.56 & -0.38 & -7.71 \\
\hline
\end{tabular}


Table 7. Allen elasticities, aggregate manufacturing

\begin{tabular}{|l|r|r|r|r|r|r|r|r|}
\hline & \multicolumn{1}{l}{ Country pooled } & \multicolumn{1}{l}{$\boldsymbol{t}$} & \multicolumn{1}{l}{ Korea } & \multicolumn{1}{l}{$\boldsymbol{l}$} & \multicolumn{1}{l|}{ India } & \multicolumn{1}{l|}{ Brazil } & \multicolumn{1}{l|}{} \\
\hline KK & -6.39 & -11.70 & -5.57 & -12.30 & -3.62 & -14.23 & -20.65 & -7.68 \\
\hline KL & 5.65 & 14.37 & 5.19 & 14.64 & 5.11 & 14.70 & 9.47 & 13.22 \\
\hline KE & 6.15 & 9.15 & 7.68 & 8.81 & 4.48 & 9.86 & 9.80 & 8.53 \\
\hline KM & 0.66 & 1.02 & 0.69 & 0.74 & 0.74 & 1.05 & 0.32 & 0.71 \\
\hline LL & -13.41 & -26.26 & -13.25 & -26.48 & -18.17 & -21.20 & -10.64 & -30.91 \\
\hline LE & -1.15 & -2.25 & -2.03 & -2.83 & -1.76 & -2.69 & -0.36 & -1.12 \\
\hline LM & 0.06 & 0.60 & 0.06 & 0.63 & -0.36 & -2.69 & 0.30 & 4.31 \\
\hline EE & -19.08 & -6.64 & -26.64 & -4.56 & -18.91 & -6.70 & -14.76 & -8.64 \\
\hline EM & -0.23 & -1.24 & -0.77 & -2.84 & -0.36 & -1.71 & 0.14 & 1.04 \\
\hline MM & -0.17 & -4.54 & -0.17 & -4.65 & -0.26 & -5.78 & -0.08 & -2.70 \\
\hline
\end{tabular}

Table 8. Price elasticities, aggregate manufacturing

\begin{tabular}{|l|c|c|c|c|c|c|c|c|}
\hline & Country pooled & $\boldsymbol{t}$ & Korea & $\boldsymbol{t}$ & India & $\boldsymbol{t}$ & Brazil & $\boldsymbol{t}$ \\
\hline KK & -1.17 & -11.70 & -1.12 & -12.30 & -0.98 & -14.23 & -1.71 & -7.68 \\
\hline KL & 0.43 & 14.37 & 0.40 & 14.64 & 0.30 & 14.70 & 0.88 & 13.22 \\
\hline KE & 0.28 & 9.15 & 0.25 & 8.81 & 0.21 & 9.86 & 0.59 & 8.53 \\
\hline KM & 0.46 & 5.27 & 0.48 & 5.99 & 0.47 & 7.82 & 0.24 & 1.27 \\
\hline LK & 1.04 & 14.37 & 1.05 & 14.64 & 1.38 & 14.70 & 0.78 & 13.22 \\
\hline LL & -1.02 & -26.26 & -1.02 & -26.48 & -1.07 & -21.20 & -0.99 & -30.91 \\
\hline LE & -0.05 & -2.25 & -0.07 & -2.83 & -0.08 & -2.69 & -0.02 & -1.12 \\
\hline LM & 0.04 & 0.60 & 0.04 & 0.63 & -0.22 & -2.69 & 0.23 & 4.31 \\
\hline EK & 1.13 & 9.15 & 1.55 & 8.81 & 1.21 & 9.86 & 0.81 & 8.53 \\
\hline EL & -0.09 & -2.25 & -0.16 & -2.83 & -0.10 & -2.69 & -0.03 & -1.12 \\
\hline EE & -0.88 & -6.64 & -0.86 & -4.56 & -0.88 & -6.70 & -0.88 & -8.64 \\
\hline EM & -0.16 & -1.24 & -0.53 & -2.84 & -0.22 & -1.71 & 0.10 & 1.04 \\
\hline MK & 0.12 & 5.27 & 0.14 & 5.99 & 0.20 & 7.82 & 0.03 & 1.27 \\
\hline ML & 0.001 & 0.60 & 0.001 & 0.63 & -0.02 & -2.69 & 0.03 & 4.31 \\
\hline ME & -0.01 & -1.24 & -0.02 & -2.84 & -0.02 & -1.71 & 0.01 & 1.04 \\
\hline MM & -0.12 & -4.54 & -0.12 & -4.65 & -0.16 & -5.78 & -0.06 & -2.70 \\
\hline
\end{tabular}

Table 9. Allen elasticities, iron and steel

\begin{tabular}{|l|r|r|r|r|r|r|}
\hline & Country pooled & \multicolumn{1}{l}{ K } & \multicolumn{1}{l|}{ Korea } & \multicolumn{1}{l|}{ India } & \multicolumn{1}{l|}{} \\
\hline KK & -2.56 & -2.72 & -3.00 & -2.64 & -2.20 & -2.78 \\
\hline KL & 1.11 & 1.54 & 1.14 & 1.24 & 1.09 & 1.88 \\
\hline KE & 1.90 & 1.22 & 1.96 & 1.18 & 1.83 & 1.27 \\
\hline KM & 1.43 & 0.35 & 1.44 & 0.39 & 1.43 & 0.32 \\
\hline LL & -21.22 & -17.63 & -24.63 & -15.08 & -18.62 & -20.14 \\
\hline LE & 0.51 & 0.35 & 0.45 & 0.27 & 0.57 & 0.43 \\
\hline LM & 0.88 & 2.01 & 0.87 & 1.82 & 0.89 & 2.14 \\
\hline EE & -24.54 & -3.21 & -23.49 & -3.26 & -24.99 & -3.19 \\
\hline EM & 1.98 & 1.33 & 1.89 & 1.40 & 2.07 & 1.28 \\
\hline MM & -1.34 & -2.80 & -1.16 & -2.78 & -1.56 & -2.81 \\
\hline
\end{tabular}


Table 10. Price elasticities, iron and steel

\begin{tabular}{|l|r|r|r|r|r|r|}
\hline & Country Pooled & \multicolumn{1}{l}{$\boldsymbol{t}$} & Korea & \multicolumn{1}{l|}{ India } & \multicolumn{1}{l|}{ 年 } \\
\hline KK & -0.93 & -2.72 & -0.99 & -2.64 & -0.87 & -2.78 \\
\hline KL & 0.05 & 1.54 & 0.04 & 1.24 & 0.05 & 1.88 \\
\hline KE & 0.13 & 1.22 & 0.14 & 1.18 & 0.13 & 1.27 \\
\hline KM & 0.75 & 2.30 & 0.81 & 2.26 & 0.69 & 2.32 \\
\hline LK & 0.40 & 1.54 & 0.38 & 1.24 & 0.43 & 1.88 \\
\hline LL & -0.90 & -17.63 & -0.90 & -15.08 & -0.90 & -20.14 \\
\hline LE & 0.04 & 0.35 & 0.03 & 0.27 & 0.04 & 0.43 \\
\hline LM & 0.46 & 2.01 & 0.49 & 1.82 & 0.43 & 2.14 \\
\hline EK & 0.69 & 1.22 & 0.65 & 1.18 & 0.73 & 1.27 \\
\hline EL & 0.02 & 0.35 & 0.02 & 0.27 & 0.03 & 0.43 \\
\hline EE & -1.74 & -3.21 & -1.72 & -3.26 & -1.76 & -3.19 \\
\hline EM & 1.03 & 1.33 & 1.06 & 1.40 & 1.00 & 1.28 \\
\hline MK & 0.52 & 2.30 & 0.48 & 2.26 & 0.57 & 2.32 \\
\hline ML & 0.04 & 2.01 & 0.03 & 1.82 & 0.04 & 2.14 \\
\hline ME & 0.14 & 1.33 & 0.14 & 1.40 & 0.15 & 1.28 \\
\hline MM & -0.70 & -2.80 & -0.65 & -2.78 & -0.75 & -2.81 \\
\hline
\end{tabular}

Own-price elasticities for energy are within the range of 0.80 and 0.82 for aggregate manufacturing and paper while for the steel sector this is greater than one showing high responsiveness of energy demand to own-price change. These numbers are comparable to similar cross-country studies of Pindyck and Griffin and Gregory for aggregate sector (Table 11).

Table 11. Long-run energy price elasticity across studies

\begin{tabular}{|c|c|c|c|c|}
\hline & Pindyck & Griffin and Gregory & Authors' (with Brazil) & Authors' (without Brazil) \\
\hline Canada & -0.87 & & & \\
\hline France & -0.83 & -0.80 & & \\
\hline Italy & -0.84 & -0.79 & & \\
\hline Japan & -0.84 & & & \\
\hline Netherlands & -0.84 & -0.78 & & \\
\hline Norway & -0.84 & -0.77 & & \\
\hline Sweden & -0.84 & & & \\
\hline UK & -0.84 & -0.80 & & \\
\hline USA & -0.85 & -0.79 & $-0.80(\mathrm{P})$ & $-1.24(\mathrm{P})$ \\
\hline Germany & -0.85 & -0.80 & & \\
\hline Belgium & & -0.77 & & \\
\hline Denmark & & -0.79 & & \\
\hline India (P, AM, I and S) & & & $-0.82,-0.88, \mathrm{NA}$ & $-1.05, \mathrm{NA},-1.76$ \\
\hline Korea (P, AM, I and S) & & & $-0.81,-0.86, \mathrm{NA}$ & $-1.21, \mathrm{NA},-1.72$ \\
\hline Brazil (P, AM, I and S) & & & $-.0 .82,-0.88, \mathrm{NA}$ & \\
\hline
\end{tabular}

Note: $\mathrm{P}=$ paper, $\mathrm{AM}=$ aggregate manufacturing, $\mathrm{I}$ and $\mathrm{S}=$ iron and steel, $\mathrm{NA}=$ not available. 
An additional interesting finding is the complementarity between certain pairs of inputs. Interpreting these estimates as long-run elasticities, one might a priori expect pervasive substitutability. However, we find complementarity between labor and energy in the paper industry in the cross-country result and for India, South Korea, and Brazil, and between labor and energy and materials and energy in all but one instance in aggregate manufacturing.

One issue that arises in this analysis is the possible effect of very high inflation in Brazil during the study period. This of course contributes to variation in the data and thus, in principle, to robustness, and might be expected a priori to result in higher measured degrees of substitutability. Table 12, Table 13, Table 14 and Table 15 show the results of the regressions with Brazil omitted (for paper and aggregate manufacturing). We see that, in fact, the magnitudes of estimated elasticities relative to those computed including Brazil varies. Given the considerably greater variation with the inclusion of the Brazil data, it may be appropriate to instead compute arc elasticities, which we leave for future work.

Table 12. Allen elasticities, paper 1 - excluding Brazil

\begin{tabular}{|l|l|r|r|r|r|r|r|r|}
\hline & Country pooled & \multicolumn{1}{l}{ U } & \multicolumn{1}{l|}{ US } & \multicolumn{1}{l|}{ Korea } & \multicolumn{1}{l|}{ India } & \multicolumn{1}{l|}{} \\
\hline KK & -4.68 & -10.65 & -15.28 & -7.58 & -7.45 & -9.32 & -1.78 & -12.81 \\
\hline KL & 1.52 & 5.05 & 1.56 & 4.80 & 2.29 & 3.05 & 1.59 & 4.61 \\
\hline KE & 0.50 & 1.06 & -0.41 & -0.31 & 0.20 & 0.26 & 0.80 & 4.23 \\
\hline KM & 1.70 & 3.07 & 2.44 & 3.47 & 1.76 & 3.30 & 1.55 & 2.82 \\
\hline LL & -8.81 & -25.36 & -3.50 & -39.35 & -20.10 & -16.87 & -23.07 & -15.84 \\
\hline LE & -2.28 & -4.42 & -1.20 & -3.47 & -6.25 & -5.48 & -3.76 & -5.02 \\
\hline LM & 1.60 & 9.62 & 1.29 & 16.08 & 1.90 & 7.64 & 2.72 & 5.71 \\
\hline EE & -16.54 & -6.53 & -23.73 & -5.29 & -20.72 & -5.72 & -10.79 & -8.45 \\
\hline EM & 2.37 & 4.86 & 2.73 & 4.43 & 2.32 & 4.94 & 2.36 & 4.87 \\
\hline MM & -1.43 & -9.95 & -1.29 & -9.86 & -0.86 & -9.21 & -2.75 & -9.77 \\
\hline
\end{tabular}

Table 13. Price elasticities, paper — excluding Brazil

\begin{tabular}{|l|r|r|r|r|r|r|r|r|}
\hline & \multicolumn{1}{l}{ Country pooled } & \multicolumn{1}{l}{$\boldsymbol{t}$} & \multicolumn{1}{l}{ US } & \multicolumn{1}{l}{ Korea } & \multicolumn{1}{l|}{ India } & \multicolumn{1}{l|}{$\boldsymbol{t}$} \\
\hline KK & -1.17 & -10.65 & -1.78 & -7.58 & -1.38 & -9.32 & -0.79 & -12.81 \\
\hline KL & 0.19 & 5.05 & 0.39 & 4.80 & 0.16 & 3.05 & 0.10 & 4.61 \\
\hline KE & 0.04 & 1.06 & -0.02 & -0.31 & 0.01 & 0.26 & 0.08 & 4.23 \\
\hline KM & 0.94 & 7.90 & 1.42 & 5.54 & 1.22 & 7.53 & 0.62 & 9.15 \\
\hline LK & 0.38 & 5.05 & 0.18 & 4.80 & 0.42 & 3.05 & 0.71 & 4.61 \\
\hline LL & -1.11 & -25.36 & -0.87 & -39.35 & -1.36 & -16.87 & -1.42 & -15.84 \\
\hline LE & -0.16 & -4.42 & -0.06 & -3.47 & -0.36 & -5.48 & -0.37 & -5.02 \\
\hline LM & 0.89 & 9.62 & 0.75 & 16.08 & 1.31 & 7.64 & 1.08 & 5.71 \\
\hline EK & 0.13 & 1.06 & -0.05 & -0.31 & 0.04 & 0.26 & 0.36 & 4.23 \\
\hline EL & -0.29 & -4.42 & -0.30 & -3.47 & -0.42 & -5.48 & -0.23 & -5.02 \\
\hline EE & -1.15 & -6.53 & -1.24 & -5.29 & -1.21 & -5.72 & -1.06 & -8.45 \\
\hline EM & 1.31 & 4.86 & 1.59 & 4.43 & 1.60 & 4.94 & 0.93 & 4.87 \\
\hline MK & 0.43 & 7.90 & 0.28 & 5.54 & 0.33 & 7.53 & 0.69 & 9.15 \\
\hline ML & 0.20 & 9.62 & 0.32 & 16.08 & 0.13 & 7.64 & 0.17 & 5.71 \\
\hline
\end{tabular}




\begin{tabular}{|l|r|r|r|r|r|r|r|r|}
\hline & \multicolumn{1}{|l|}{ Country pooled } & \multicolumn{1}{l|}{$\boldsymbol{t}$} & US & \multicolumn{1}{l|}{ K } & \multicolumn{1}{l|}{ Korea } & \multicolumn{1}{l|}{ India } & \multicolumn{1}{l|}{} \\
\hline $\mathrm{ME}$ & 0.17 & 4.86 & 0.14 & 4.43 & 0.14 & 4.94 & 0.23 & 4.87 \\
\hline $\mathrm{MM}$ & -0.79 & -9.95 & -0.75 & -9.86 & -0.59 & -9.21 & -1.09 & -9.77 \\
\hline
\end{tabular}

Table 14. Allen elasticities, aggregate manufacturing — excluding Brazil

\begin{tabular}{|l|r|r|r|r|r|r|}
\hline & Country pooled & \multicolumn{1}{l}{$\boldsymbol{t}$} & \multicolumn{1}{l|}{ Korea } & \multicolumn{1}{l|}{ India } & \multicolumn{1}{l|}{} \\
\hline KK & -4.92 & -4.75 & -6.18 & -4.43 & -4.02 & -5.04 \\
\hline KL & 1.90 & 3.03 & 1.91 & 2.99 & 1.89 & 3.01 \\
\hline KE & 4.72 & 3.11 & 6.24 & 2.92 & 3.77 & 3.34 \\
\hline KM & 1.27 & 0.53 & 1.30 & 0.47 & 1.25 & 0.59 \\
\hline LL & -18.13 & -27.46 & -15.41 & -30.00 & -21.89 & -24.85 \\
\hline LE & 2.71 & 1.97 & 2.83 & 1.92 & 2.68 & 1.98 \\
\hline LM & 1.04 & 3.60 & 1.03 & 4.24 & 1.05 & 2.99 \\
\hline EE & -6.56 & -1.57 & -3.55 & -0.58 & -7.72 & -2.56 \\
\hline EM & -1.57 & -2.20 & -1.98 & -2.40 & -1.29 & -2.03 \\
\hline MM & -0.47 & -2.44 & -0.40 & -2.31 & -0.54 & -2.54 \\
\hline
\end{tabular}

Table 15. Price elasticities, aggregate manufacturing - excluding Brazil

\begin{tabular}{|c|c|c|c|c|c|c|}
\hline & Country Pooled & $t$ & Korea & $t$ & India & $t$ \\
\hline KK & -1.15 & -4.75 & -1.25 & -4.43 & -1.07 & -5.04 \\
\hline KL & 0.13 & 3.03 & 0.15 & 2.99 & 0.11 & 3.01 \\
\hline $\mathrm{KE}$ & 0.19 & 3.11 & 0.20 & 2.92 & 0.17 & 3.34 \\
\hline KM & 0.84 & 2.98 & 0.90 & 2.75 & 0.79 & 3.19 \\
\hline LK & 0.44 & 3.03 & 0.39 & 2.99 & 0.51 & 3.01 \\
\hline LL & -1.23 & -27.46 & -1.19 & -30.00 & -1.29 & -24.85 \\
\hline LE & 0.11 & 1.97 & 0.09 & 1.92 & 0.12 & 1.98 \\
\hline LM & 0.68 & 3.60 & 0.71 & 4.24 & 0.66 & 2.99 \\
\hline EK & 1.11 & 3.11 & 1.26 & 2.92 & 1.01 & 3.34 \\
\hline EL & 0.18 & 1.97 & 0.22 & 1.92 & 0.16 & 1.98 \\
\hline EE & -0.26 & -1.57 & -0.12 & -0.58 & -0.36 & -2.56 \\
\hline EM & -1.03 & -2.20 & -1.36 & -2.40 & -0.81 & -2.03 \\
\hline MK & 0.30 & 2.98 & 0.26 & 2.75 & 0.33 & 3.19 \\
\hline ML & 0.07 & 3.60 & 0.08 & 4.24 & 0.06 & 2.99 \\
\hline $\mathrm{ME}$ & -0.06 & -2.20 & -0.06 & -2.40 & -0.06 & -2.03 \\
\hline MM & -0.31 & -2.44 & -0.28 & -2.31 & -0.34 & -2.54 \\
\hline
\end{tabular}

\section{Remarks on implications for integrated assessment models}

In general terms, we have found higher magnitudes of elasticities of substitution than appear to be commonly used in integrated assessment and/or energy-economic simulation models. An experiment applying these results to one such model, by increasing the parameter governing inter-factor substitution, led to rather interesting changes in abatement cost curves and reference case scenarios, with one outcome being higher carbon emissions in the reference case (Sathaye et 
al., 2001). The explanation appears to involve interaction between the degree of substitutability in the model, on the one hand, and the relative magnitudes of factor-specific productivity growth rates, on the other. Labor productivity growth dominates that for other factors, so that in equilibrium the relative price of labor in future years is higher, and the underlying "tendency" of the representative firms in the model is to thus substituted away from labor. Increasing the ease with which energy can be substituted amplifies this effect, thereby increasing energy demand (relative to the reference case parameterization) and hence carbon emissions. However, abatement costs are less with new elasticity values compared to default values.

A second difference between the model we have estimated here and the standard representation of production in integrated assessment models is that our translog model includes no assumption of separability. By contrast, nested (separable) constant-elasticity-of-substitution and other "nonflexible" functional forms are the norm in simulation models. Table 16 shows the results of a number of tests of pair-wise separability restrictions using the "linear" and "nonlinear" tests described by Berndt and Wood (1975). As the table indicates, and as previous researchers have found, these restrictions are, overall, rather weakly supported in our data.

Table 16. Pair-wise weak separability tests

\begin{tabular}{|c|c|c|c|c|c|c|}
\hline \multirow[t]{2}{*}{ Nesting structure } & \multicolumn{2}{|c|}{$(\mathrm{KE})(\mathrm{LM})$} & \multicolumn{2}{|c|}{$(\mathrm{KL})(\mathrm{EM})$} & \multicolumn{2}{|c|}{ (LE) (KM) } \\
\hline & $\mathbf{L}$ & NL & $\mathbf{L}$ & NL & $\mathbf{L}$ & NL \\
\hline Pooled paper & $\mathrm{R}$ & FTR & FTR & FTR & $\mathrm{R}$ & $\mathrm{R}$ \\
\hline Pooled agg. manufacturing & $\mathrm{R}$ & FTR & $\mathrm{R}$ & $\mathrm{R}$ & $\mathrm{R}$ & FTR \\
\hline Pooled iron and steel & $\mathrm{R}$ & $\mathrm{R}$ & $\mathrm{R}$ & $\mathrm{R}$ & $\mathrm{R}$ & $\mathrm{R}$ \\
\hline
\end{tabular}

Note: $\mathrm{R}=$ rejected, $\mathrm{FTR}=$ fail to reject, $\mathrm{L}=$ linear, $\mathrm{NL}=$ nonlinear.

These issues - the appropriate magnitude of substitution elasticities and the validity of separability assumptions - are examples of empirical questions that bear on the construction and application of integrated assessment models, but in recent years have received relatively little attention in the literature. We believe that the results reported here indicate the value of further research on such questions and their implications for long-run energy and carbon abatement policy modeling.

\section{Acknowledgements}

We thank John Houghton of the Office of Biological and Environmental Research, U. S. Department of Energy, for supporting this work, Larry Dale for his advice, and Katja Schumacher for contributions to the research effort. Any errors are the sole responsibility of the authors. Work at Lawrence Berkeley National Laboratory was supported under the US. Department of Energy Contract No. DE-AC03-SF00098. 


\section{References}

Bank of Korea 1 (various years) Bank of Korea 1 (various years): Economic Statistics Yearbook 1979, 1990, 1996. The Bank of Korea.

Bank of Korea 2 (various years) Bank of Korea 2 (various years): Producer Prices Survey, 197394. Monthly Publication of The Bank of Korea.

Berndt and Wood, 1975 Ernst R. Berndt and David O. Wood, Technology, prices, and the derived demand for energy, The Review of Economics and Statistics 58 (1975) (3), pp. 259268 (August).

Binswanger, 1978 H.P. Binswanger, Induced technical change: evolution of thought. In: H.P. Binswanger and V.W. Ruttan, Editors, Induced Innovation-Technology, Institutions, and Development, The Johns Hopkins University Press, Baltimore (1978).

Christensen et al., 1971 L.R. Christensen, Dale Jorgenson and L.J. Lau, Conjugate duality and the transcendental logarithmic production function, Econometrica 39 (1971), pp. 255-256.

Fundacao Instituto Brasileiro de Geografia e Estatistica (IBGE 1) (various years) Fundacao Instituto Brasileiro de Geografia e Estatistica (IBGE 1) (various years). Pesquisa Industrial. Secretaria de Planejamento da Presidencia da Republica. Departamento de Industrias. Brazil. Fundacao Instituto Brasileiro de Geografia e Estatistica (IBGE 2) (various years) Fundacao Instituto Brasileiro de Geografia e Estatistica (IBGE 2) (various years). Censo Industrial. Secretaria de Planejamento da Presidencia da Republica. Departamento de Industrias. Brazil.

Fuss, 1977 Melvyn A. Fuss, The demand for energy in Canadian manufacturing — an example of the estimation of production structures with many inputs, Journal of Econometrics 5 (1977), pp. 89-116.

Government of India 1 (various years) Government of India 1 (various years). Annual Survey of Industries: Summary Results for Factory Sector, 1973-1993. New Delhi (India): Central Statistical Organisation, Department of Statistics, Ministry of Planning and Programme Implementation.

Government of India 2 (various years) Government of India 2 (various years). Index Numbers of Wholesale Prices in India, 1973-1993. New Delhi (India): Office of the Economic Advisor, Ministry of Finance.

Greene, 1997 W.H. Greene, Econometric Analysis, Prentice Hall, New Jersey (1997).

Griffin and Gregory, 1976 G.M. Griffin and P.R. Gregory, An intercountry translog model of energy substitution responses, American Economic (1976), pp. 845-857 (December).

Jorgenson and Fraumeni, 1981 D.W. Jorgenson and Barbara M. Fraumeni, Relative prices and technical change. In: E.R. Berndt and B. Fields, Editors, Modeling and Measuring Natural Resources Substitution, MIT Press, Cambridge (1981).

Jorgenson et al., 1987 D.W. Jorgenson, F.M. Gollop and M. Fraumeni, Productivity and U.S. economic growth, North Holland, Amsterdam (1987).

Kravis et al., 1978 I.B. Kravis, A.W. Heston and R. Summers, International Comparisons of Real Product and Purchasing Power, The Johns Hopkins University Press, Baltimore (1978).

Perroni and Rutherford, 1998 Carlo. Perroni and Thomas F. Rutherford, A comparison of the performance of flexible functional forms for use in applied general equilibrium modelling, Computational Economics 11 (1998) (3), pp. 245-263 (June). Full Text via CrossRef $\mid \underline{\text { View }}$

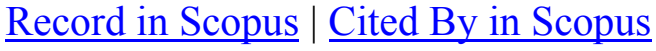


Pindyck, 1979 Robert S. Pindyck, Interfuel substitution and the industrial demand for energy: an international comparison, Review of Economics and Statistics (1979), pp. 169-179 (May). Roy, 1992 Joyashree Roy, Demand for Energy in Indian Manufacturing Industries, Daya Publishing, Delhi (1992).

Roy, 1995 Joyashree Roy, Allen or Morishima elasticities? Some empirical evidence from Indian manufacturing industries, Arthavijnana XXXVII (1995) (1), pp. 66-76.

Roy et al., 1999 Joyashree Roy, J. Sathaye, A. Sanstad, P. Mongia and K. Schumacher, Productivity trends in India's energy intensive industries, The Energy Journal 20 (1999) (3), pp. 32-61.

Roy et al., 2001 Joyashree Roy, Jayant Sathaye, Alan Sanstad and Katja Schumacher, Patterns of fuel input use and technological change in India's energy-intensive industries, Proceedings of the 24th IAEE International Conference, 2001: an Energy Odyssey, held in Houseton, USA (2001).

Ryan and Wales, 2000 David L. Ryan and Terence J. Wales, Imposing local concavity in the translog and generalized Leontief cost functions, Economics Letters 67 (2000), pp. 253-260.

Schumacher et al., 2000 Katja Schumacher, J. Roy and J. Sathaye, Productivity Trends in Energy Intensive Industries in Brazil, India and South Korea, $L B N L$ vol. 45499, Lawrence Berkeley National Laboratory (2000).

Sathaye et al., 2001 Jayant Sathaye, Joyashree Roy, Katja Schumacher, Alan Sanstad, Yurie Tanimichi and Ron Sands, Ron, 2001. Projecting Carbon Emissions and Abatement Costs in Developing Countries: Impact of Country-specific Substitution Elasticities,, Presented at A Joint Meeting of the Energy Modeling Forum, International Energy Agency and the International Energy Workshop at IIASA, Laxenburg, Austria 19-21 June 2001 (2001). 